\title{
System of balanced indicators as the basis of the organizational effectiveness model
}

\author{
Ekaterina Bykova \\ Belarusian State Agrarian Technical University, Minsk, Republic of Belarus
}

\begin{abstract}
Based on the results of the study, the necessity of using modern methods for assessing the performance indicators of an organization is substantiated. From a variety of methods, a balanced KPI scorecard for poultry enterprises was selected. The process of strategic analysis in all case studies in various fields. It is a research procedure, very useful for experts in the field of data analysis from different points of view.

This system more fully reflects the strategic goals and objectives that any organization seeks.

Criteria for choosing a system of balanced indicators are determined taking into account the specifics of the industry sector of organizations.

A mechanism has been developed to form a system of balanced indicators for the development of organizations. This mechanism includes the stages of the formation of a system of balanced indicators and the characteristic features of the implementation of each stage.

Based on the analysis of the organizational structure and specialization of the organization, middle managers were selected who are responsible for the performance of KPI indicators. The basic functional tasks for each of the managers are proposed depending on the specific KPI indicator.
\end{abstract}

Key words: balance, scorecard, poultry-farming, effectiveness.

Corresponding author: Ekaterina Bykova

E-mail: kkatarina@ list.ru

DOI: 10.24263/RES-2019-12

\section{Introduction}

One of the most important conditions for the competitive development of an organization is to take into account multifaceted influence factors, which can be implemented using the strategic analysis method, which allows a comprehensive assessment of industry factors and factors of marko-and microenvironment, as well as taking into account the degree of influence.

Within the framework of the presented criteria, qualitative assessment methods, such as a SWOT analysis, a McKinsey matrix, a SWN analysis, a PEST analysis, etc. can be used. At the present stage, quantitative estimates of the organization's development goals are no less significant. 
Among the quantitative indicators of the formation of strategic goals and program activities, poultry organizations most often stand out indicators of financial stability and the results of production and economic activity (profitability of the enterprise, profitability of assets, profit from sales of products, etc.).

One of the conditions for the successful development of an enterprise is a correctly substantiated and formulated policy and strategy, on the basis of which the organization's management line is built to improve its performance.

The general growth of the introduction of information technologies in business processes and the subsequent development of information systems that take into account the specifics of organizations' activities necessitates the coordination of the organization's general strategy and the informatization strategy.

The effective strategic management is possible when using and accounting for indicators that determine the target setting in various areas of business. According to E.Y. Voronova stated problems will be solved by a balanced scorecard - an enterprise management system based on measuring and evaluating its effectiveness by a set of indicators that reflect all aspects of the activity, that are significant from the point of view of strategy (financial, manufacturing, marketing, innovative, etc.) [1, p. 108].

In the context of the growing need for timely management decisions in the framework of the ever-changing external environment of the organization, there is a need to use modern models of organizational effectiveness.

One of the options for this model can be a comprehensive model of organizational effectiveness, taking into account:

- $\quad$ system-resource model, which involves the rational use of unique and rare resources;

- the target model, the main task of which is to achieve the organization's goals;

- models of participants' satisfaction based on an assessment of the quality characteristics or evaluations of the organization's activities by its employees.

The integrated use of all of the above models is possible in the preparation of specific goals and objectives. The implementation of the strategic goals and development goals of the organization today should be carried out using reference points of growth and control, selected from a wide range of indicators - the balanced performance system (KPI - Key Performance Indicator) [7]. This system of indicators determines the effectiveness of the organization's business in the following groups of factors:

- financial factors;

- factors of development of the organization's staff;

- factors of the effectiveness of internal business processes;

- factors of efficiency of work with consumers [2, p. 96].

The presented system is flexible for modification depending on the chosen development strategy of the organization and allows achieving target goals due to the synergy of interaction between components of the organization's business. 


\section{Results and discussion}

The presented mechanism for developing a system of balanced indicators for the development of organizations includes one of the most significant stages - drawing up a strategic goal map, which indicates goals depending on a group of factors and their impact on the ultimate general goal [9].

In this case, the selection of specific indicators and their recognition as key is accompanied by an assessment of them according to the following parameters:

- Reflects and measures the strategic points of development of the organization;

- Based on common standard measurements;

- Based on real data;

- Easy to interpret;

- Relevant;

- Represented by a positive effect $[10,11]$

On the example of OJSC "1st Minsk Poultry Factory" based on the organizational structure of the enterprise, streamlined information flows, functional tasks, responsibilities of middle and senior managers, table 1 presents a list of balanced indicators of strategic management accounting [7].

Table 1

Mechanism for developing a system of balanced indicators of development of organizations [8]

\begin{tabular}{|l|l|}
\hline Stage & Characteristic \\
\hline Goal Definition & $\begin{array}{l}\text { Determination of the main goals and objectives of the organization's } \\
\text { development (ranking by degree of importance) for four groups of } \\
\text { factors and their compliance with the general goal. }\end{array}$ \\
\hline Strategic Mapping & $\begin{array}{l}\text { Identification of the causal relationship of the proposed goals, their } \\
\text { adjustment and selection. Planning strategic communications, } \\
\text { information support for managers. }\end{array}$ \\
\hline Create metrics & Interpretation of presented interlinked goals in quantitative indicators. \\
\hline Setting target values & $\begin{array}{l}\text { Drawing up target values of selected indicators taking into account the } \\
\text { starting point of organization detail. }\end{array}$ \\
\hline $\begin{array}{l}\text { Development } \\
\text { strategic activities }\end{array}$ & $\begin{array}{l}\text { Concretization of activities contributing to the achievement of BSC } \\
\text { indicators, the choice of terms of implementation and responsible } \\
\text { persons. }\end{array}$ \\
\hline Implementation BSC & Project implementation and monitoring of its implementation. \\
\hline
\end{tabular}

The main activities of OJSC "1st Minsk Poultry Factory" are the production of poultry products (eggs and poultry meat) and their processing, the production of dairy products and crop production is partially represented, commercial activity with the right to wholesale and retail trade is actively developing.

A local network has been established in the organization for information transfer, and management information is recorded in a software product on the 1C: Enterprise 
7.7 platform from 1C: BITRIX. Within the framework of this information system, automation of certain areas of management accounting is presented: fixed assets, material assets, animals for growing and fattening, labor and wages, finished products, including shipping and sales, financial transactions, other means and sources [9].

The presented indicators should be taken into account in the process of forecasting and monitoring the organization's activities by responsible persons, who must respond in a timely manner and adjust their actions if necessary. This balanced scorecard within the framework of a comprehensive model of organizational effectiveness is advisory in nature, in the process a more detailed selection of significant components is possible [4].

Table 2

Balanced scorecard for strategic management accounting of a poultry organization [10]

\begin{tabular}{|c|c|c|}
\hline Groups & Indicators & Responsible \\
\hline $\begin{array}{l}\text { Financial } \\
\text { performance }\end{array}$ & $\begin{array}{l}\text { 1. Return on assets, production, sales. } \\
\text { 2. Financial stability and solvency. } \\
\text { 3. The value of the business. }\end{array}$ & $\begin{array}{l}\text { Deputy gene. director of } \\
\text { finance and economics, } \\
\text { chief accountant and chief } \\
\text { economist }\end{array}$ \\
\hline Staff development & $\begin{array}{l}\text { 1. Level of qualification. } \\
\text { 2. The degree of satisfaction and } \\
\text { motivation, commitment to the } \\
\text { organization. } \\
\text { 3. The level of automation of information } \\
\text { support. }\end{array}$ & $\begin{array}{l}\text { Deputy gene. director for } \\
\text { ideology, head of human } \\
\text { resources, head of ACS }\end{array}$ \\
\hline $\begin{array}{l}\text { Consumer } \\
\text { Performance } \\
\text { Indicators }\end{array}$ & $\begin{array}{l}\text { 1. The level of customer loyalty. } \\
\text { 2. Market share, the development trend of } \\
\text { new markets. } \\
\text { 3. Consideration of potential customer } \\
\text { needs. }\end{array}$ & $\begin{array}{l}\text { Deputy gene. director of } \\
\text { commercial affairs, head } \\
\text { of FEA, head of marketing } \\
\text { and head of sales }\end{array}$ \\
\hline $\begin{array}{l}\text { Performance } \\
\text { indicators of } \\
\text { internal business } \\
\text { processes [11] }\end{array}$ & $\begin{array}{l}\text { 1. Innovative susceptibility of the } \\
\text { organization. } \\
\text { 2. Logistics. } \\
\text { 3. Management costs, production costs. }\end{array}$ & $\begin{array}{l}\text { Head of the planning and } \\
\text { economic department, } \\
\text { head of the department of } \\
\text { logistics, chief economist }\end{array}$ \\
\hline
\end{tabular}

\section{Conclusion}

The priority of indicators and their values should be formed according to the strategic vision and mission of the organization, taking into account trends in factors and the external environment (target model). The above indicators in the form of separate elements do not represent the possibility of a full-fledged analysis of the organization's details, for this reason a comprehensive, systematic approach to assessing organizational effectiveness is required taking into account the distribution of the weight coefficients of each indicator based on available resources and their significance (system-resource model). 
Moreover, in this case, the most optimal will be the use of group methods for making managerial decisions among top and middle managers as an interpretation of a qualitative assessment of the organization's activity (participants' satisfaction model) $[8,11]$.

Summarizing, it is necessary to note the need to use a balanced scorecard system in the process of creating a comprehensive model of organizational effectiveness in combination with an information system for providing analytics and the possibility of making managerial decisions of the ERP II class, which includes accounting for all production business processes and their relationship with external contractors.

\section{References}

1. Voronova E.Y (2010), Neo-institutional analysis of the accounting process: a training manual, MGIMO, Moscow.

2. Voronin A.D., Korolev A.V. (2014), Strategic management: a training manual, Higher School, Minsk.

3. Kim L.I. (2016) Strategic Management Accounting, INFRA, Moscow.

4. Bykova E.Y. (2018), Balanced system of indicators of strategic management accounting, Economic development of the state and social stability: materials of the II International Science-Practical Conference, pp. 219-220.

5. Vasilkov A.V., Vasilkov A.A., Vasilkov I.A. (2015), Information systems and their security: a training manual, Forum, Moscow.

6. Golitsyna O.L., Maximov N.V., Popov I.I. (2016), Information systems: textbook, FORUM, Moscow.

7. Sanchez-Marqueza R., Albarracin J., Guillemb M., Vicens-Salortc E., Jabaloyes J. (2018) A statistical system management method to tackle data uncertainty when using key performance indicators of the balanced scorecard, Journal of Manufacturing Systems, 48, pp. 166-179.

8. Sophocles N. B., Panagiotis D. Z. (2012) Developing a step-by-step effectiveness assessment model for customer-oriented service organizations, European Journal of Operational Research, 223(1), pp. 226-233.

9. Jian Y., Bing S., Shuai T., Hongbo S. (2019) Concurrent monitoring of globallocal performance indicators for large-scale process, Journal of the Taiwan Institute of Chemical Engineers, 102, pp. 9-16.

10. Elhadjamora E.A., Ghannouchib S.A. (2019), Analyze in Depth Health Care Business Process and Key Performance Indicators using Process Mining, Procedia Computer Science, 164, pp. 610-617.

11. Banu G. S. (2018), Measuring innovation using key performance indicators, Procedia Manufacturing, 22, pp. 906-911. 